Original article

\title{
Yenilikçi Mutfak Akımlarının Türk Mutfağı Kapsamında Uygulanabilirliği ve Yerel Mutfağın Menülerde Kullanılması İle İlgili Görüşlerin Belirlenmesi
}

\section{Determination of Views on the Applicability of Innovative Culinary Currents in Turkish Cuisine and Using Local Cuisine in Menus}

\author{
Melahat Yıldırım Saçılık \\ Department of Tourism and Management, Faculty of Tourism, Bandırma Onyedi Eylül University, Balıkesir, Turkey
}

\begin{abstract}
Özet
Yiyecek ve içecekte farklıık adına geliştirilen yöntem ve tekniklerin şekillendirdiği yenilikçi mutfak akımları, gastronomide çeşitliliğin artmasına neden olmaktadır. Yenilikçi mutfak akımlarında amaç, mevcut yemek reçetelerini geliştirerek ya da farklı pişirme teknikleri kullanarak yeni gastronomik ürünler ortaya koymaktır. Dünya genelinde yenilikçi mutfak uygulamaları "Nouvelle Cuisine” adı ile nitelendirilmektedir. Türk mutfağı içinde barındırdığı farklı etnik yapıların etkisiyle şekillenerek yiyecek içecek malzeme ve pişirme teknikleri açısından çok çeşitliliğe sahip bir mutfak haline gelmiştir. Böylesine geniş yapıda gelişimini devam ettiren Türk mutfağı uygulayıcılarının yeniliğe açık olup olmadıklarının ortaya çıkarılması üzerine şekillenen bu çalışmada, yenilikçi mutfak akımlarından füzyon mutfak ve moleküler mutfak akımlarının Türk mutfağında uygulanmasına ve yerel mutfağın menülerde kullanılmasına dair bilgi ve görüşleri ortaya koyma amacı güdülmüştür. Yarı yapılandırılmış soru formu ve kolayda örnekleme yöntemi ile Muğla Sıtkı Koçman Üniversitesi Turizm Fakültesi Yiyecek-Içecek İşletmeciliği Bölümü ve Marmaris Meslek Yüksekokulu Aşçılık Bölümü öğrencileri ile Muğla ili Marmaris ilçesinde faaliyet gösteren 24 adet beş yıldızlı otellerin mutfak şeflerinden veri elde edilmiştir. Kolayda örnekleme yöntemi ile 76'sı öğrenci ve 8’i alanında uzman şeflerden veri elde edilmiştir. Veriler, nitel araştırma yöntemlerinden içerik analizi ile çözümlenmiştir ve katılımcılara ait tüm görüşler değiştirilmeden analize alınmıştır. Çalışmanın sonucunda katıımcıların yenilikçi mutfak akımları konusunda donanımlı olmadıkları ve bu tür uygulamaların yöresel yemeklerin sürdürülebilirliğine zarar vereceği ve bu yüzden yerel mutfağın menülerde kullanılmasının gerekliğini savundukları görülmüştür.
\end{abstract}

Anahtar Kelimeler: Füzyon Mutfak, Moleküler Mutfak, Türk Mutfağı, Yenilikçi Mutfak Akımları, Yerel Mutfak.

\begin{abstract}
Innovative culinary currents, in which methods and techniques developed for the sake of difference in food and beverage are described, cause an increase in diversity in gastronomy. The purpose of the current innovative cuisine, to reveal new gastronomic meal recipes or improving existing products using different cooking techniques. Innovative cuisine applications around the world are described as "Nouvelle Cuisine". Turkish cuisine has become a cuisine with a wide variety in terms of food and beverage materials and cooking techniques by being shaped by the influence of different ethnic structures. In this study, which was shaped on the basis of revealing whether the Turkish cuisine practitioners, who continue to develop in such a wide structure, are open to
\end{abstract}

\footnotetext{
* Corresponding author:

Melahat Yıldırım Saçılık, Department of Tourism and Management, Faculty of Tourism, Bandırma Onyedi Eylül University, Balıkesir, Turkey. Email:msacilik@bandirma.edu.tr
} 
innovation, it is aimed to reveal the knowledge and opinions about the application of fusion cuisine and molecular cuisine trends in Turkish cuisine and the use of local cuisine in menus. With the semi-structured questionnaire and easy sampling method, data was obtained from Muğla Sıtkı Koçman University Tourism Faculty Food and Beverage Management Department and Marmaris Vocational School Culinary Department and the kitchen chefs of 24 five-star hotels operating in Marmaris district of Muğla province. Data were obtained from 76 students and 8 expert chefs with easy sampling method. The data were analyzed with content analysis, one of the qualitative research methods, and all opinions of the participants were analyzed without changing. As a result of the study, it was seen that the participants were not equipped with innovative culinary trends and that such practices would harm the sustainability of local dishes and therefore they defended the necessity of using the local cuisine in the menus.

Keywords: Innovative Culinary Currents, Fusion Cuisine, Molecular Cuisine, Local Cuisine.

DOI: https://doi.org/10.29329/jtm.2020.289.2

\section{GíRiş}

Sınıfsal/etnik/siyasal kimliği belirleyen ideolojilerin göstergesi (Fırat, 2014:130) olan yemeğin üretimi ve sunumu arasındaki işlemlerin bir ifadesi olan gastronomi; yenilik, farklılık ve çeşitliliğin oluşmasına imkân veren bir bilim dalıdır. Gastronomi kültürel yapının gözler önüne serildiği bir sanat dalı olarak da görülebilmektedir. İnsanlar için yemek fizyolojik bir ihtiyaç, kültürel bir olgu, ticari bir ürün, estetik bir değer ya da sosyal bir ifade ve iletişim aracıdır (Aksoy ve Üner, 2016:1). Yiyecek içecekte yenilik, farklılık ve çeşitlilik arayan tüketicilere hitap etme çabasında olan mutfak üreticileri, yenilikçi mutfak akımlarını araştırma, öğrenme ve hatta uygulama yönünde uğraşı vermektedirler. Hall ve Mitchell, (2002) iletişim ve ulaşım teknolojisindeki ilerlemelerle birlikte gida ve bilginin dünya çapında aktarılması ile sağlandığını ileri sürmüşlerdir. Günümüz modern şefleri, eğitim ve teknolojik gelişmeler eşliğinde geleneksel tarifleri farklılaştırarak yeni tat ve sunumlar gerçekleştirmektedirler.

Yiyecek ve içecekte çeşitlilik, farklılık ve yenilik arayışı, farklı kültürlere ait yemek malzemelerini farklı pişirme teknikleri kullanarak tek bir tabakta toplayabilme çabasını beraberinde getirmiştir. Mutfakta geleneksellikten çıkarak yeniliğe yönelme anlamını taşıan "Nouvelle Cuisine", klasik mutfağı durağanlıktan çıkarmış ve dinamik bir atmosfere sokmuştur. Dünyada olduğu gibi Türkiye'de de mutfakta yenilik uygulamaları büyük bir hızla uygulanabilmektedir. Bu çalışma, mutfaklarda değişiklik, yenilik ve farklılık adına uygulanan yenilikçi mutfak akımlarından füzyon mutfak ve moleküler mutfak uygulamalarının Türk mutfağında uygulanması üzerine şekillenmiştir. Hâlihazırda yiyecek içecek sektöründe faaliyet gösteren mutfak şefleri ve gelecek yiyecek içecek sektöründe yer alma eğilimi taşıyan öğrencilerin, yenilikçi mutfak akımlarının Türk mutfağında uygulanıp uygulanmaması ve bunların gerekçelerinin neler olduğu konusundaki görüşleri ortaya çıkarılmaya çalışılmıştır. 
Yenilikçi mutfak uygulamalarının farkındalığının bir ölçütü olma sebebiyle çalışma, önem taşımaktadır. Yenilikçi mutfak akımları ile ilgili araştırmaların giderek yaygınlaştığı literatür incelemesinde varılan bir sonuçtur. Fakat yiyecek içecek konusunda eğitim alan ve aktif çalışan kişilerin görüşlerinin ve bu bağlamda algılarının ortaya çıkarılmana dair az sayıda çalışmaya rastlanmıştır. Mutfak gelişiminde mutfak çalışanlarının eğitimi, araştırma eğilimi ve uygulama becerilerinin rolü bulunmaktadır. Çalışmada; yiyecek içecek ve aşçılık eğitimi alan öğrenciler ile alanında uzman şeflerin yenilikçi mutfaklar hakkındaki görüşleri belirlenmiş ve yiyecek içecek konusundaki bilgi eksikliğine ya da yanlış anlayışlara değinilmiştir. Çalışma yiyecek içecek sektöründe uzun yıllar işlev yapan şefler ile bu alanda hâlihazırda eğitim alan öğrencilerin, yenilikçi mutfak akımları konusunda tam anlamıyla bilgi sahibi olup olmadıkları ve bu uygulamaları kullanıp kullanmadıklarının ortaya konulması ve sektörel yapıdaki bu bilgi eksikliğinin giderilmesi konusunda öneriler sunması açısından önem arz etmektedir. Çalışmada ilk olarak yenilikçi mutfak, füzyon mutfak, moleküler mutfak ve yerel mutfak kavramsal olarak açıklanmıştır. İkinci aşamada uygulana yöntem ve sonrasında örneklemden elde edilen görüşler ele alınmıştır.

\section{Kavramsal Çerçeve}

Sosyalleşme algısı çerçevesinde ortaya çıkan dışarıda yemek yeme alışkanlığının yiyecek içecek endüstrisinde bir dönüşüme sebebiyet verdiğini vurgulayan Karamustafa, Birdir ve K1lıçhan, (2016) bu dönüşümün farklı mutfak uygulamalarının gelişmesinde etkin bir role sahip olduğunu ifade etmişlerdir. Okech'a (2014) göre hayatın devamlılığını sağlayan yemek olgusu, insanların sosyal ve psikolojik ihtiyaçlarını gidermede önemli bir araç olmuştur. İletişim ve ulaşımda yaşanan gelişimler sayesinde farklı kültürlerle tanışma ve mutfak kültürünün yer ve zaman sınırlaması olmadan bir sirkülasyona maruz kalması aracılığıyla yerelde yeni mutfak uygulamaları hız kazanmıştır (Kanık, 2016:43). Aksoy ve Üner'e (2016) göre popüler medyada sürekli dile getirilen yeme-içme kültürü, izleyicilerin yemeiçme eğilimlerini de şekillendirmiştir. Dünya genelinde yaşanan göç dalgaları aracılığıyla insanlar farklı kültürlerle tanışmış ve yemek malzemeleri ile pişirme tekniklerini kendi yaşadıkları yerlerde uygulamaya başlamışlardır.

Fransa'da 18. yüzyılın ilk yarısında ortaya çıkan ve diğer ülkelerin mutfaklarını da etkisi altına alan yenilikçi mutfak akımlarında eski yöntemler radikal bir biçimde basitleştirilirken mutfaklara bilimsel yaklaşımları da ortak etmiştir. Buna sağlık, diyet ve yemeğin kimyası gibi unsurlar etki etmiştir. Sonraki süreçte restoran kurumunun gelişimi ve yemek eleştirmenliği kavramının doğuşu, mutfakta yeniliği teşvik etmiş; aşçılar arasında rekabet giderek artarken restoranların müşteri nüfusu da artış göstermiştir (Aksoy ve Üner, 2016:6). Yenilikçi mutfak akımı (nouvelle cuisine) dünya literatürüne "Nouvelle Cuisine" olarak geçmiş ve Fransız mutfak tarihinde geleneksellikten kopuş ve yeniliğe yöneliş olarak nitelendirilmektedir. "Ortodoks” klasik mutfağına karşı bir başkaldırış olan yenilikçi 
mutfağın öncüleri "Gault ve Milau” mutfaklarda eskinin reddedilmesi için 10 kural öne sürmüşlerdir (Gourmand, 2015: Erişim: 10.12.2020). Bunlar:

- Yemek pişirmede aşırı karmaşıklıktan kaçınılması gerekmektedir.

- Çoğu balık, deniz ürünü, av kuşları, dana eti, yeşil sebzeler ve börekler için pişirme sürelerinin azaltılması, ürünlerin doğal lezzetlerinin korunması açısından büyük önem arz etmektedir.

- Yemeklerde mümkün olan en taze malzemelerin tercih edilerek yemeğin kalite ve görünümü artırılmalıdır.

- Daha kısa menüler hazırlanarak karmaşıklıktan kaçınılmalıdır.

- Et ve av eti için güçlü turşular kullanılmamalıdır. Bu sağllk açısından önem arz eden bir unsurdur.

- Yemeklerini taze otlar, kaliteli tereyağl, limon suyu ve sirke ile tatlandırmak için espagnole ve beşamel gibi ağır soslar yerine hafif soslar tercih edilmesi sindirimi kolaylaştırır.

- Klasik mutfak yemeklerinin yerine yöresel yemeklerin ilham kaynağı olarak tercih edilmesi, yerel mutfă̆ın sürdürülebilirliği için bir gerekliliktir.

- Yeni tekniklerin benimsenmesi ve modern ekipmanların kullanılması, mutfakta yenilikçiliğin gelişmesine yardımcı olur.

- Şefler, misafirlerin kültürel özelliklerine, sağlık koşullarına uygun meniler çıkarmalıdır.

- Şeflerin son derece yaratıcı olarak yeni kombinasyonlar ve eşleşmeler gerçekleştirerek yaratıcı menüler ortaya koymaları, yenilikçilik adına yapılabilecek uygulamalardır.

Nouvelle cuisine bir sanat, bir bilim, bir duyu patlaması ve günlük yaşamdan sağladığı kaçışa özlem duyan, hem yemek meraklıları hem de genel halkın zevkleri için bir tedavi yöntemidir (Gourmand, 2015, Erişim: 10.12.2020). Yenilikçi, mutfak hareketi, klasik mutfağa karşıt olarak ortaya çıkmıştır ve basitlik, hayal gücü, sağlık gibi değerler odağında şekillenmiştir. Klasik mutfak; restoran sahibinin gücünü, büyük stoklar ve az tazelik gerektiren uzun menüler, tabak dışındaki ritüeller, flambe hazırlıkları ve uzun bir tüketim sürecini vurgularken yenilikçi mutfak ise taze malzemeler ve düşük stoklar gerektiren kısa menüler, tabaktan servis ve kısa bir tüketim süreci ile şefin özerkliğini vurgulamaktadır (Rao, Monin ve Durand, 2003:798). Bu akım, küçük porsiyonlar eşliğinde yemekte lezzet, görünüş ve sunumun etkileyici olması üzerine odaklanmaktadır. 


\section{Füzyon Mutfak}

Kültürel etkileşimlerin etkisiyle farklı ulus mutfaklarının aynı mutfak çatısı altında birleşmesiyle füzyon mutfak akımı ortaya çıkmıştır (Aksoy ve Üner, 2016:108). Füzyon mutfak, farklı mutfak kültürlerinin sahip olduğu teknikleri, malzemeleri ya da ürünleri bir araya getirerek ortaya farklı lezzetler sunmayı amaç edinen bir gastronomi akımıdır. Füzyon mutfak uygulamaları, bir yandan mutfak kültürünün korunmasını sağlarken diğer yandan mutfak kültürüne evrensel bir özellik kazandırmaktadır (Turan, Başaran, Ayduğ, Bayesen ve Sünnetçioğlu, 2020:332). Ayrıca füzyon mutfak uygulamaları, mutfaklarda geleneksellikle modernliğin buluşmasını sağlar

Farklı ulusların pişirme yöntemleri ve malzemelerini aynı tabakta bilinçli bir şekilde buluşturan; yenilikçi, özgün ve yaratıcı bir akım olarak nitelendirilen füzyon mutfağı; 1980'li yıllarda Batı teknik ve malzemeleri ile Uzakdoğu teknik ve malzemelerinin birleştirilmesi ile ortaya çıkmıştır (Sandıkçı ve Çelik, 2007: 42; Doğdubay, Girgin ve Giritlioğlu, 2007:39). Henüz yeni bir kavram olarak görülen "füzyon mutfak" terimi yüzyıllardan beri uygulanagelmektedir. Mutfak dünyalarının yeni ve hibrit yemekler yaratmak için harmanlanması olarak tanımlanan füzyon mutfak, ticaretin başlamasından bu yana yüzyıllardır sürmektedir. Kültürler birbirlerine yaklaşmasıyla insanların yeni konseptler ve lezzet profilleri oluşturmak için pişirme stillerini ve malzemelerini paylaşması ve birleştirmesi ile yeni yemeklerin ortaya çıktığı görülmektedir (Tarınç, Yıldırım ve Kılınç, 2019:3046).

Füzyon mutfak akımı en az iki farklı mutfakta bulunan malzemeler, baharatlar ve kendine özgü değişik teknikleri birleştirerek tamamen farklı bir yiyecek ortaya çıkartmayı amaçlamaktadır. Füzyon mutfak günümüzde yiyecek içecek işletmelerinde ürün geliştirme stratejisi olarak da kullanılmaktadır. Füzyon mutfak, farklı yemek anlayış ve kavramlarının sentezlenmesi sonucu oluşan yeni mutfaklar, yeni yemekler ve yeni lezzetlerdir (Doğdubay, Şahin ve Yiğit, 2017:2). Füzyon mutfak, genellikle farklı yemek kültürlerinden malzemeleri ve teknikleri birleştiren bir pişirme tarzını ifade etmektedir. Bir mutfak kültürüne dayalı yiyecekler, başka bir kültüre özgü içerikler, tatlar ve teknikler kullanılarak hazırlanmaktadır (Stano, 2014: 905). Uyar ve Zengin (2015) füzyon mutfak uygulamalarını üç farklı nitelikte tanımlamışlardır.

Füzyon mutfak, farklı kültürdeki yakın bölgelerin yemeklerinden birleştirilen uygulamalardır.

Füzyon mutfak, yemeklerden birinin belirleyici ve baskın olup diğer mutfak veya mutfakların teknik ve malzemelerinin de kullanıldığı uygulamalardır (eklektik).

Füzyon mutfak, belirleyici ve baskın mutfak olmadan tüm dünya mutfaklarının kullanımının mümkün olduğu uygulamalar. 
Farklı yemek anlayış ve kavramlarının sentezlenmesi üç yöntem 1şı̆̆ında gerçekleşmektedir. İlk yöntem, birbirine yakın bölgelerdeki farklı kültürlere ait yemeklerin birleşimidir. İkinci yöntem; belirleyici bir yemek kültürü yanında diğer mutfaklara ait malzeme ve pişirme tekniklerinin kullanımıdır. Bu yöntem aynı zamanda "elektrik” olarak nitelendirilmektedir. Son yöntem ise bir mutfak belirleyicisi olmadan bütün dünya mutfaklarının birleştirilmesidir (Adlam, 2012; aktaran: Sarığlan, 2014:64). Bir amaç doğrultusunda bilinçli olarak farklı uluslara ait mutfakların tek bir tabakta buluşturulması anlamına gelen füzyon mutfak, bir yenilik yaklaşımıdır (Can, Sünnetçioğlu ve DurluÖzkaya 2012:873). Füzyon mutfak; kültürlerarası tarzın farklı ve genellikle de zıt geleneklerden gelen unsurlarla kaynaşmasını yansıtmaktadır. Bu kaynaşma, bilinçli şekilde yaratılan sonuçların çeşitli sanat formlarında post moderni karakterize eden referanslar arası dinamik ilişkiyi göstermektedir (McWilliams, 2006: 307). Günümüzdeki mutfakların çoğu, küreselleşme sürecinin hızlanması, medya ve seyahat yoluyla kültürel akışların artması, tüketici kültürünün gelişmesi, yemek kitabı endüstrisinin genişlemesi, tüm dünyadaki şeflerin tanınırlığı, gıda ve restoran endüstrisinin büyümesi ve sağlıklı yaşam tarzı ile ilgili sosyal ve kültürel koşulların değişimi füzyon mutfağının gelişimine katkıda bulunmaktadır. Füzyon mutfağı ve yeni yemekler ile ilgili paylaşımlar tüketici bilgisini ve talebi arttırmaktadır. Günümüz tüketicileri sağlıklı yaşam tarzları ile daha fazla ilgilenmektedir ve füzyon mutfağının çeşitli mutfakların en sağlıklı unsurlarını bir araya getirmesi füzyon mutfağının faydalı çıktıları arasında yer almaktadır (Tarınç vd., 2019:3046).

\section{Moleküler Mutfak}

Globalleşme ve beraberinde yaşanan teknolojik, ekonomik, sosyolojik gelişmeler yeme-içme sektörü açısından da çok farklı değişimlere neden olmaktadır. Yemek pişirmeye dair son dönemde artan ilgi yoğunluğu ile birlikte yediklerimizin doğası ve etkileşimlerini belirleyen kimyasal ve fiziksel ilkeleri anlama isteği de artmıştır (Özel ve Özkaya, 2016:50). Blanck, (2007) moleküler mutfağın, gıdaların yemeğe dönüştürülme sürecinde uygulanan her işlemin, tüketilen besinler üzerinde oluşturduğu etkileşim ve değişimleri anlama isteği ile birlikte ortaya çıkan bir akım olduğunu belirtmiştir.

Yemek pişirmek özellikle son dönemlerde spesifik ve bilimsel çalışmaların yapıldığı alanların bir parçası haline gelmiştir. Bu bilimsel disiplin Nicholas Kurti ve Herve This tarafından moleküler gastronomi olarak tanımlanmıştır. This, (2013) moleküler gastronomiyi yemek biliminin bir dalı olarak tanımlamıştır. Ancak yemeğin içine girenlerin fiziği ve kimyasından farklı olarak yiyeceklerin dönüşümlerini ve bu aşamadaki kimyasal olayları içermektedir. Akerdem, (2009) yiyecek ve içecekleri biyokimyasal ve fiziki-kimyasal süreçlerden geçirilerek değişik şekil ve tatlarda hazırlayarak sunmak olarak tanımlanabilen özgün, yaratıcı ve yenilikçi bir teknik olan moleküler gastronomi uygulamaları 1990’lı yıllarda dünya mutfaklarında adından söz ettirmeye başlamıştır. Moleküler mutfak genellikle moleküler gastonomi ile karıştırılmaktadır. Moleküler gastronomi bir bilim dalı iken moleküler mutfak uygulama alanıdır (Durlu Özkaya ve Özel, 2018, s.55). Vega ve Ubbink’e (2008) göre moleküler 
gastronomi, gastronomi biliminde zaman içerisinde ortaya çıan yeni araştırma alanlarından birisi haline gelmiştir. This (2013) moleküler gastronominin temel amacının, mevcut durumu iyileştirmek, yeni yiyecek hazırlama yöntemleri geliştirmek ve bunların sonucunda hazırlanan ürünün tadının her seferinde aynı olmasını sağlamak olduğunu ifade etmiştir. Bir başka tanımlamada This, (2013) moleküler gastronomiyi bir pişirme türü değil, yiyeceklerin pişirme aşamasında birbirine dönüşüm sürecini inceleyen bir bilim dalı olarak betimlemiştir. Bilim temelli pişirme yöntemi olan moleküler mutfak uygulamalarında yeni araçlara, katkı maddelerine ve yöntemlere gereksinim duyulur. Moleküler mutfak, moleküler gastronomi ile elde edilen bilgileri kullanan yenilikçi bir mutfak akımıdır. Moleküler gastronomi ise var olan durum, olay ve olguları ortaya koyan ve bunların arasındaki ilişkileri araştıran bilimsel bir disiplindir.

Moleküler mutfağın öncüleri olan Oxford Üniversitesi fizikçisi Nicholas Kurti ve Fransız kimyager Herve This, 1988 yılında moleküler mutfak ile ilgili tanımlamalara kesinlik kazandırılmıştır. Barham, Skibsted, Bredie, Bom Frost, Risbo ve Snitkjer (2010) moleküler mutfağı gıdaların pişirilmesi sırasında oluşan fiziksel-kimyasal değişimleri ve gıdayı oluşturan bileşenlerinin neden olduğu duyusal algılamayı açıklayan disiplinler arası bir bilim dalı olarak tanımlamışlardır. Yenilikçi mutfak akımı çerçevesinde gelişen moleküler mutfağın özelliği, teknoloji kullanarak gıda ürünlerinin moleküler yapılarıyla oynamak ve aynı zamanda bir araya gelmesi öngörülmeyen yemek malzemelerini birlikte sunmaktır. Mielby ve Frøst'a (2010) göre moleküler mutfak, yiyecek ve içeceklerin insana zevk ve keyif veren özelliklerinin bilimsel incelemesi ve lezzetli olmanın bilimidir. Santich (2004) moleküler mutfağı, teknolojiyi kullanarak fizik ve kimya bilimleri 1şı̆̆ında yiyecek ve içecekleri değişik şekil ve lezzetlerde hazırlamak ve sunmak olarak tanımlamıştır. Vega ve Ubbink, (2008) moleküler mutfağı yemek pişirme sırasında ortaya çıkan besin ürünlerinin fiziksel ve kimyasal değişimlerini inceleyen bir bilim dalı olarak görmektedirler. Moleküler mutfağın temel amacı mevcut durumu iyileştirmek, yeni yiyecek hazırlama yöntemleri geliştirmek ve bunların sonucunda hazırlanan ürünün tadının her seferinde aynı olmasını sağlamaktır.

\section{Yerel Mutfak ve Türk Mutfağı}

Yerel mutfak kavramı Şengül ve Türkay (2015) tarafından yöreye has kültür ve ürünlerin birleşiminden oluşan, yörede yaşayanların sahip oldukları milli ve dini özelliklere göre tasarlanan, özgün pişirme ve sunum farklılıkları olan bir mutfak türü şeklinde tanımlanmaktadır. Bucak ve Ateş (2014) yerel mutfak kültüründe etkili olan unsurların; coğrafi özellikler, tarih, ekonomi ve din olduğunu öne sürmüşlerdir. Yazarlar, dünyadaki bütün toplumlar kendilerine ait bir mutfak kültürüne ve beslenme biçimlerine sahip olduğunu ve bu beslenme biçimlerinin, içinde bulunulan kültürel, coğrafi, ekonomik, ekolojik yapıya, dine ve tarihsel sürece göre şekillendiğini belirtmişlerdir.

Yemek, bir kültürün maddi unsurlarının başında gelir ve insanların beslenme ihtiyacını karşılayan araçlardır. Ulusların kültürel özellikleri yemeklerin hazırlanmasında, pişirilmesinde ve sunumunda 
farklılıkların oluşmasının ana nedenidir. Söz konusu yemek kültüründeki bu farklılıklar “mutfak” olarak nitelendirilmektedir. Bireysel ihtiyaçtan doğarak toplum kültürünün bir parçası olan yemek ve bu kültürün yansıtılmasına aracı olan mutfağın yaşatılabilmesi ve sürdürülebilirliğinin sağlanması gerekir (Yıldırım Saçılık ve Baysal, 2019:86). Kızıldemir, Öztürk ve Sarışık (2014) yerel mutfağı, her bölge ve her ülke için farklılıklar arz eden ve o bölge veya ülkenin yereli olan mutfak olarak tanımlamışlar ve dünya mutfağı olarak bilinen her mutfak türünün, kendi bölgesi için bir yerel mutfak özelliği gösterdiğini ileri sürmüşlerdir. Türk mutfak kültürünün Türk milletine özel yerelliği içerdiğini ifade eden yazarlar, Türk mutfağının Orta Asya dönemi, Selçuklu ve Beylikler dönemi, Osmanlı saray ve halk mutfağı ile Cumhuriyet dönemi mutfağı şeklinde süreçler yaşayarak zenginleşmiş ve değişmiş olduğunu beyan etmişlerdir. Yerel mutfak, yörenin kültürünü yansıtarak yörenin kalkınma ve sürdürülebilirliği açısından önem taşımaktadır. Yerel mutfakların menülerde sıklıkla kullanılması kültürel kimliğin yok olmaması ve gastronomik mirasın özellikle yeni nesil tarafından benimsenmesini ve uygulamasını sağlar. Menülerde yer alabilecek yerel yemek ürünleri, gastronomik mirasın tanınırlığını artırdığı gibi gelecek kuşaklara bu kültürel mirasın aktarımı da daha kolay olacaktır. Böylelikle köklerine bağlı ama bir o kadar da yenilikçi nesiller yetişmesi sağlanabilecektir. Yerel yemek kültürünün gelecek kuşaklara aktarımı ancak ve ancak, bu lezzetlerin yemek hizmeti veren hemen her işletmede sıklıkla kullanımı ile mümkündür.

Dünya mutfakları arasında önemli bir yeri olan Türk mutfağı, tarihsel süreç içerisinde farklı toplumlarla girdiği kültürel etkileşim sonucu, kendi zengin mutfak kültürünü meydana getirmiştir (Karaca ve Karacaoğlu, 2016:561). Hemen her bölgesinde farklı kültürlerin yaşadığı, bu kültürlere ait yeme içme alışkanlıklarının iç içe geçtiği Türkiye coğrafyası, yenilikçi mutfak uygulamalarının gerçekleşmesi için uygun yapısal özelliğe sahiptir. Avcıkurt, Sarığlu ve Girgin, (2007) coğrafî, kültürel ve sosyolojik sebeplerle, Türklerin, komşuluk münasebetlerinde bulundukları ve iç içe yaşamış oldukları farklı toplumlarla etnolojik anlamda hem etnik vericilik hem de etnik alıcılık yaptıklarını ve bu alışverişin hiç kuskusuz yiyecek ve içecek kültürü için de söz konusu olduğunu ifade etmektedir.

Türk mutfağı, coğrafyasında barındırdığı kültürel çeşitlilik sayesinde çok çeşitliliğe sahiptir. İnceöz (2009) günümüz Türk Mutfağı'nın, Türkiye'de yaşamış tüm uygarlıkların etkisiyle gelişmiş ve zenginleşmiş olduğunu belirtmiştir. Can vd. (2012) Türk mutfağının Sümer, Mısır, Antik Yunan vb. medeniyetlerin etkisiyle ortaya çıkan bir mutfak olmadığını belirtmiş ve Türk mutfağının oluşumuna etki eden bir süreç olarak değerlendirmiştir. Yazarlar, Fransız mutfağı, Çin Mutfağı ve İtalya mutfağı gibi diğer mutfaklarında benzer süreci yaşadıklarını ve tüm dünya mutfaklarının bir füzyon mutfak olduğunu ileri sürmüştür. 


\section{YÖNTEM}

\section{Çalışmanın Amacı}

Çalışmanın amacı; yenilikçi mutfak akımlarının (füzyon mutfak ve moleküler mutfak) Türk mutfağında uygulanabilmesi ve yerel mutfağın menülerde kullanılması ile ilgili görüşlerin belirlenmesidir. Araştırmanın ortaya koymak istediği problem, yiyecek içecek sektöründe işlev yapan şefler ve gelecekte bu mesleği tercih etme eğilimi olan öğrencilerin, yenilikçi mutfak uygulamaları hakkında bilinçli olup olmadıklarının ve bu akımları doğru kullanıp kullanmadıklarının belirlenmesidir. Araştırma verileri ışığında gerçekleştirilen analiz sonuçları, dünya mutfakları arasında önemli yeri bulunan Türk mutfağının, yeni akımlar çerçevesinde ilerleyebilmesine engel teşkil eden bilgi eksikliğini gözler önüne sermesi ve bu konuda yapılabilecekler hakkında sunulan öneriler açısından çalışma önem arz etmektedir.

\section{Araştırma Evren ve Örneklemi}

Araştırmanın evrenini Muğla Sıtkı Koçman Üniversitesi Turizm İşletmeciliği Programı Aşçılık ve Yiyecek İçecek İşletmeciliği bölüm öğrencileri ve Muğla Marmaris’te faaliyet gösteren yıldızlı otellerin şef aşçıları oluşturmaktadır. Söz konusu evren, çalışmanın amacı çerçevesinde daraltılarak örneklem oluşturulmuştur. Kolayda örnekleme yöntemi ile yiyecek içecek konusunda hâlihazırda eğitim alan ve aktif çalışan 76 katılımcıdan veri elde edilmiştir.

\section{Veri Toplama ve Analiz Tekniği}

Araştırma örnekleminden 2019 yılı Ekim-Kasım ve Aralık aylarında katılımcılardan görüşme tekniği ile veri elde edilmiştir. Katılımcıların algı ve görüşlerinin ortaya konulmasında veri toplamada görüşme yöntemi öne çıkmaktadır. Görüşmede kullanılan temel yöntem ise sözlü iletişimdir. Görüşme yöntemi insanların tecrübelerini, duygularını ve algılarını ortaya koymada kullanılan güçlü bir yöntemdir (Yıldırım ve Şimşek, 2013). Nitel araştırma yöntemin doğrultusunda katılımcıların yenilikçi mutfakların Türk mutfağına uygulanabilirliği konusundaki görüş ve algılarını belirleme amacıyla yarı yapılandırılmış soru formu hazırlanmış ve görüşme yöntemiyle örneklemden 70 adet veri elde edilmiştir. Veriler içerik analizi ile çözümlenmiştir. Tablo 1'de katılımcılara yöneltilen sorular yer almaktadır.

Tablo 1. Katılımc1lara Yöneltilen Sorular

\begin{tabular}{|l|l|}
\hline $\begin{array}{l}\text { Füzyon mutfağın Türk mutfağına uygulanmasına yönelik } \\
\text { düşünceleriniz nelerdir? }\end{array}$ & $\begin{array}{l}\text { Uygulansın / Uygulanmasın } \\
\text { Çünkü...... }\end{array}$ \\
\hline $\begin{array}{l}\text { Moleküler mutfağın Türk mutfağına uygulanmasına yönelik } \\
\text { düşünceleriniz nelerdir? }\end{array}$ & Uygulansın / Uygulanmasın \\
\hline $\begin{array}{l}\text { Yerel mutfă̆ın menü...... } \\
\text { nelerdir? }\end{array}$ & Kullanılsın / Kullanılmasın \\
\hline
\end{tabular}




\section{Bulgular}

Araştırmaya katılanların yaşları, eğitim durumları, mesleki tecrübeleri ve mutfaktaki uzmanlık alanlarına ait bilgiler Tablo 2'de gösterilmiştir.

Tablo 2. Katılımcılara Ait Özellikler

\begin{tabular}{|c|c|l|c|c|l|}
\hline Yaş & Kişi Sayısı & Ĕğitim & $\begin{array}{c}\text { Adet } \\
\text { Mesleki Tecrübe } \\
\text { (Yıl) }\end{array}$ & Uzmanlık \\
\hline 18 & 6 & Lisans (Şef) & 2 & 10 & \\
19 & 3 & Önlisans (Şef) & 3 & $10-11$ & \\
20 & 14 & Lise(Şef) & 2 & $8-4$ & \\
21 & 10 & İlköğretim(Şef) & 1 & 22 & \\
22 & 17 & Öğrenci (Lisans) & 26 & & Yiyecek İçecek Bölümü \\
23 & 8 & Öğrenci (Önisans) & 36 & & Aş̧̧ıllk Bölümü \\
24 & 2 & TOPLAM & 70 & & \\
25 & 2 & ŞEF STATÜLERİ & & & \\
27 & 1 & Executive Chef & & 30 & Ala Carte \\
28 & 2 & Sous Chef & 1 & 22 & Türk Mutfağı \\
29 & 1 & Sous Chef & 1 & 22 & Sicak-Soğuk Mutfak \\
33 & 1 & Chef De Partie & 1 & 16 & Soğuk Mutfak \\
37 & 1 & Chef De Partie & 1 & 11 & Sicak Mutfak \\
38 & 1 & Chef De Partie & 1 & 10 & Sicak-Soğuk Mutfak \\
47 & 1 & Chef De Partie & 1 & 8 & Sicak-Soğuk Mutfak \\
18 & 6 & Chef De Partie & 1 & 4 & Sicak-Soğuk Mutfak \\
\hline
\end{tabular}

Araştırmaya lisans düzeyinde eğitim gören 29 ve önlisans düzeyinde eğitim gören 39 öğrenci ile mesleki tecrübeleri 4 ile 30 yıl arasında değişen 8 adet üst düzey aşçı katılmıştır. Aşçıbaşı ve aşçıbaş1 yardımcıları olan şeflerin uzmanlık alanları Ala Carte, Türk Mutfăğ, soğuk ve sıcak mutfak olarak belirtilmiştir.

Füzyon mutfağın Türk mutfağına uygulanması konusunda katılımcıların düşünceleri sorulmuş ve 57 katılımcı uygulanması gerektiğini savunurken 13 katılımcı uygulanmaması yönünde olumuz görüş belirtmişlerdir. Araştırmaya katılanların füzyon mutfağın Türk mutfağında uygulanmasına yönelik olumlu görüşleri Tablo 3’te gösterilmiştir. 
Tablo 3. Füzyon Mutfağın Türk Mutfağına Uygulanmasına Dair Katılımcıların Olumlu Görüşleri

\begin{tabular}{|c|c|}
\hline Çeşitlilik & Değer \\
\hline $\begin{array}{l}\text { Yemek çeşitliliğimize uygun; } \\
\text { Güzel tatlar yakalanabilir; } \\
\text { Çok çeşitli yiyecek-içeceklerin farklı kültürlerle } \\
\text { harmanlanması daha lezzetli ve görsel tanımlamalar } \\
\text { oluşturabilir; }\end{array}$ & $\begin{array}{l}\text { Türk mutfağına değer katar, gelişir; } \\
\text { Türk mutfağının farklı mutfaklar ile etkinleşerek görünüm } \\
\text { zenginliği yaratır; } \\
\text { Türk mutfağının değeri artar; } \\
\text { Osmanlı mutfağı da füzyon mutfağı sayılır ve eşsiz } \\
\text { yemekler barındırır. }\end{array}$ \\
\hline Farklılık & Yenilikçilik \\
\hline $\begin{array}{l}\text { Farklı tatlıların bir araya gelmesi güzel sonuçlar doğurur; } \\
\text { Farklı tatları bir arada tutmak için; } \\
\text { Her türlü farklılığın yiyeceklerdeki etkisini görmek isterim; } \\
\text { Farklı mutfak uygulamalarının birleşmesiyle çıkan tatları } \\
\text { severim; } \\
\text { Farklı lezzetleri birlikte buluşmasını sağlar; } \\
\text { Farklı kültürlerin yemek yeme noktasında birleşmesi } \\
\text { önemlidir; } \\
\text { Değişik tatlar iyidir; } \\
\text { Farklı şeyler bilmek bir adım önde olmak gibidir } \\
\text { Her türlü farklılığın yiyeceklerdeki etkisini görmek isterim }\end{array}$ & $\begin{array}{l}\text { Yeni tat ve lezzetler ortaya çıkar; } \\
\text { Tekniklerin iç içe geçmesi mutfağa yenilik katabilir; } \\
\text { Yeniliklere açık olmak gerek; } \\
\text { Yeni lezzetler daha çok talebe neden olur; } \\
\text { Yeniliği peşinden getirir; } \\
\text { Türk mutfağı çok geniş bir mutfak yeni lezzetlerin ortaya } \\
\text { çıması füzyon ile mümkün; } \\
\text { Farklı tat ve pişirme teknikleri deneyimlemeliyiz yeniliğe } \\
\text { açık olmalıyız; } \\
\text { Orijinalini bozmadan uygulansın; } \\
\text { Farkl1lığı ve güzelliği peşinden getirir; } \\
\text { Çok çeşitli yemeklerimiz daha da atar }\end{array}$ \\
\hline Gelişim & Kültürel Birleșim \\
\hline $\begin{array}{l}\text { Mutfağın gelişimine yardımcı olur; } \\
\text { Türk mutfağının ilerlemesi için; } \\
\text { Türk mutfağının gelişmesini sağlar; } \\
\text { Uygulanan teknikler pişirme yöntemleri Türk mutfağına } \\
\text { farklı bir görünüm sunar; } \\
\text { Kültüre sahip çıkılarak ileriye taşınıyor; } \\
\text { Farklı tat-teknik ve uygulamalar ortaya çıkar; } \\
\text { Yabancı mutfaklardan çok Türk mutfağı hak ediyor; } \\
\text { Güzel tatlar yakalanabilir; } \\
\text { Türk mutfağının adından söz ettirebilmek için; } \\
\text { Mutfağın gelişimine yardımcı olur } \\
\text { Tekniklerin iç içe geçmesi mutfağa yenilik katabilir; } \\
\text { Yeni lezzetler daha çok talebe neden olur; } \\
\text { Türk mutfağı farklı tatlara ve yöntemlere açık bir mutfaktır; } \\
\text { Farklı şeyler bilmek bir adım önde olmak gibidir. } \\
\text { Farklı kültürler etkileşim halinde olmayı sağlar; }\end{array}$ & $\begin{array}{l}\text { Farklı kültürler ile birleşirse çok daha farklı tatlar- teknikler } \\
\text { olabilir; } \\
\text { Farklı kültürlerin birleşimi güzel olabilir risk daha düşüktür; } \\
\text { Farklı kültürlerin yemek yeme noktasında birleşmesi } \\
\text { önemlidir; } \\
\text { Farklı kültürdeki mutfakların tadılması, ağız tadını ve } \\
\text { kültürünü geliştirir; } \\
\text { Kültüre sahip çıkılarak ileriye taşınıyor; } \\
\text { Farklı tatlar tatmak ve Türk mutfağına yenilik gelmesini } \\
\text { isterim; } \\
\text { Farklı tatlıların bir araya gelmesi güzel sonuçlar doğurur. } \\
\text { Farklı kültürdeki mutfakların tadılması, ağı tadını ve } \\
\text { kültürünü geliştirir }\end{array}$ \\
\hline Tanitım & Yaraticılık \\
\hline $\begin{array}{l}\text { Turistlerin ilgisini çekebilir; } \\
\text { Aydın'ın inciri, Antalya'nın portakalını herhangi bir ülkenin } \\
\text { meyvesiyle bir tatlı yapıp adımızı duyurabiliriz. } \\
\text { Gastronomik özelliklerimizi tanıtabiliriz. }\end{array}$ & $\begin{array}{l}\text { Dünya mutfak kültürüne ses getirecek reçeteler ortaya } \\
\text { çıabilir } \\
\text { Yeni lezzetler ortaya çıkması için; } \\
\text { İlgi çekici bir uygulama; } \\
\text { Daha üst düzey bir görünüm dikkat çekebilir } \\
\text { Ceșitlilik yaratıcılıkla birleșirse daha iyi olur. }\end{array}$ \\
\hline
\end{tabular}

Füzyon mutfağın Türk mutfağına uygulanması gerektiğini belirten katılımcıların öne sürdüğü gerekçeler sekiz kategoride sınıflandırılmıştır. Katılımcıların füzyon mutfak kavramına ilişkin görüşleri ortak özellikleri bakımından incelenmiştir. Ortak özelliklere göre kategorilere ayrılan görüşler, “çeşitlilik”, "değer", "farklılık”, "gelişim”, "kültürel sürdürülebilirlik”, "tanıtım”ve "yaratıcılık” olarak isimlendirilmiştir. Araştırmaya katılanların füzyon mutfağın Türk mutfağında uygulanmasına yönelik olumsuz görüşleri Tablo 4'te gösterilmiştir. 
Tablo 4. Füzyon Mutfağın Türk Mutfağına Uygulanmasına Dair Katılımcıların Olumsuz Görüşleri

\begin{tabular}{|l|l|}
\hline Türk mutfağı şu an ki haliyle yeterince güzel & Birbirinden bağımsız olduğunu düşünüyorum \\
Eski usul candır & Her kültürün kendi ve ayrı özelliği var \\
Türk insanının damak tadı her şeye müsait değildir & Tat kayması olur \\
Türk yemekleri böyle daha güzel & Türk mutfağının korunması için uygun görmüyorum \\
Türk mutfağı mevcut durumunu muhafaza etmeli & Değişmesini istemem \\
Türk mutfağının temelini ve özünü bozamaz & Türk insanının damak tadı bozulmamalıdır. \\
Türk mutfağının yeterince geniş çaplı olduğunu & \\
düşünüyorum & \\
\hline
\end{tabular}

Moleküler mutfağın Türk mutfağına uygulanması konusunda katılımcıların düşünceleri sorulmuş ve 38 katılımcı uygulanması gerektiğini savunurken 32 katılımc1 uygulanmaması yönünde olumuz görüş belirtmişlerdir. Katılımcıların moleküler mutfağın Türk mutfağında uygulanmasına dair olumlu görüşleri Tablo 5'te verilmiştir.

Tablo 5. Moleküler Mutfağın Türk Mutfağına Uygulanmasına Dair Katılımcıların Olumlu Görüşler

\begin{tabular}{|c|c|}
\hline Değer Katma & Farklılık \\
\hline $\begin{array}{l}\text { Türk mutfağına değer katar; } \\
\text { Türk mutfağının zenginliği farklı türlerle } \\
\text { harmanlandığında daha güzel göz önünde olabilir; } \\
\text { Yiyeceklerin kalitesi artar; } \\
\text { Daha fazla değer katacağı ve merak uyandırdığı için; } \\
\text { Çok kapsamlı mutfağa sahibiz ve yenilikler } \\
\text { mutfağımıza değer katar } \\
\text { İnsanlar damak zevkini geliştirmek ve bu dalda } \\
\text { yükselmek isteyebilir; } \\
\text { Sıra dışı yemekler Türk mutfağına olan ilgiyi } \\
\text { arttırabilir; } \\
\text { Bilimsel yöntemlerle yapılan yemekler hem eğlence } \\
\text { hem de keyif katacaktır } \\
\text { Türk mutfağına yeni lezzetlerle çeşitlilik sağlanabilir; } \\
\text { Sunumu güzelleştirir. }\end{array}$ & $\begin{array}{l}\text { İnsanların farklı bir mutfak görmeleri ve denemeleri güzel olur; } \\
\text { Farklı bir görünüm olmalı ve sıvıdan katıya görmek iyi olabilir; } \\
\text { Farklı teknik, tat, servis gibi bileşenleri bizim mutfağa } \\
\text { uyarlanırsa daha iyi bir mutfak kültürüne sahip oluruz. } \\
\text { Değişik olacağına inanıyorum; } \\
\text { Farklı tatlar tatmak iyi olur; } \\
\text { Daha çeşitli ve faklı lezzetler ortaya çıkar; } \\
\text { Farklı bir mutfak deneyimi; } \\
\text { Farklı tatlar ortaya çıkar; } \\
\text { Farklı lezzetler ortaya çıkabilir } \\
\text { Farklılık ve var olan yemeklerin farklılaştırılması; } \\
\text { Pişirme tekniklerinin değişmesi farklı tatlar çıkarır; } \\
\text { Farklı tatları Anadolu tatlarıyla harmanlamak iyidir }\end{array}$ \\
\hline Gelişim & Yenilikçilik \\
\hline $\begin{array}{l}\text { Türk mutfağının ilerlemesi için; } \\
\text { Türk mutfağının gelişmesine yardımcı olur; } \\
\text { Türk mutfağında bir araya geldiğinde güzel yemekler } \\
\text { çıkacağını düşündüğum ürünler var; } \\
\text { Gastronomi alanında daha iyi yerlere gidebiliriz; } \\
\text { Tek bir bakış açısıyla ilerleyemeyiz at gözlüklerini } \\
\text { çıkarmamız lazım; } \\
\text { Yemeğin duygusal bir deneyime dönüşmesine } \\
\text { yardımcı olur. }\end{array}$ & $\begin{array}{l}\text { Yeni lezzet ve sunumları birleştirip yeni tatlar elde edilir; } \\
\text { Yenilik / zamana ayak uydurmak; } \\
\text { Türk mutfağına yenilik gelmesini isterim; } \\
\text { Yeniliklere açık olmak gerek; } \\
\text { Yenilikçilik müşteriyi her zaman memnun eder; } \\
\text { Gelişen teknikleri ve uygulamalar yeni ürünler ortaya } \\
\text { çıkarabilir. }\end{array}$ \\
\hline \multicolumn{2}{|c|}{ Tanitım } \\
\hline \multicolumn{2}{|c|}{$\begin{array}{l}\text { Türk mutfağı dünya mutfağı içinde adını duyurur; } \\
\text { Ülkemizde dikkat çekeceğine inanıyorum } \\
\text { Türk mutfağının dokunuşlar ile dünya mutfağına farklı şekilde de sunulması için } \\
\text { Yenilik ve tanıtıma ihtiyacımız var }\end{array}$} \\
\hline
\end{tabular}

Moleküler mutfağın Türk mutfağına uygulanması gerektiğini belirten katılımcıların öne sürdüğü gerekçeler ortak özellikleri bakımından incelenmiştir ve 5 kategoride sınıflandırılmıştır. Ortak 
özelliklere göre kategorilere ayrılan görüşler; "değer katma”, "farkl1lık”, "gelişim”, “yenilikçilik” ve “tanıtım” olarak isimlendirilmiştir. Katılımcıların moleküler mutfağın Türk mutfağında uygulanmasına yönelik olumsuz görüşleri Tablo 6'da verilmiştir.

Tablo 6. Moleküler Mutfağın Türk Mutfağına Uygulanmasına Dair Katılımcıların Olumsuz Görüşleri

\begin{tabular}{|l|l|}
\hline Sağlık açısından zararlı görüyorum & Yöreselliği tercih ederim \\
Türk mutfağı öğ̈̈n biçiminde korunup aktarılmalıdır & Türk mutfağının özgün kalması daha iyidir \\
İş sahası küçülecek & Ortaya çıkacak ürünlerin iyi olacağını düşünmüyorum \\
Orijinalliğin bozulmaması gerektiğini düşünüyorum & Sektörde yeterince eğitimli çalışan yok \\
Yemekte tat konusunda değişikliler olur & Türk mutfağının olduğu gibi devam etmesi önemli \\
Tadı değişir & Bence Türk mutfağı bu tekniklere uygun değil \\
Her kültürün özelliği var & Yemek yapılırken fiziksel ve kimyasal uygulanması \\
Birbirinden bağımsız olduğunu düşünüyorum & tadı değiştirir \\
Aşçılar önce Türk mutfağını öğrensin ondan sonra & Sağlıksız \\
uygulanabilir & Kültürel aktarım olamaz \\
Kültürümüze uygun değil & Otantiklik sağlanamaz \\
Yemek yapılırken fiziksel ve kimyasal uygulanmasına & Tat değişimi olur \\
gerek yok & Kültürel özerklik bozulur \\
Türk mutfağının yeterince geniş çaplı olduğunu & Bağımsız mutfaklar \\
düşünüyorum & Öncelik Türk mutfağı \\
Öz kültür yoksunluğuna karşıyım & Yöreselliği tercih ederim \\
Türk mutfağın doğallığı en güzeli & Türk mutfağının özgün kalması daha iyidir \\
Tercih edilmesinde ki risk çok fazla & \\
Türk mutfağına yakışır mı bilemiyorum kararsızım. & \\
\hline
\end{tabular}

Yöresel mutfakların Türk mutfağına uygulanması konusunda katılımcıların düşünceleri sorulmuş ve tüm katılımcılar uygulanması yönünde olumlu görüş belirtmişlerdir (Tablo 7). 
Tablo 7. Yerel Mutfağın Menülerde Kullanılmasına Dair Katılımcıların Olumlu Görüşleri

\begin{tabular}{|c|c|}
\hline Tanitım & $\begin{array}{l}\text { Kültürel } \\
\text { Sürdürülebilirlik }\end{array}$ \\
\hline $\begin{array}{l}\text { Gelen misafirlerin o kültürün sadece deniz, kum, } \\
\text { güneşi için gelmemesi için; } \\
\text { Turizmde memleketimizin yemekleri tanıtılır } \\
\text { Tanıtım için } \\
\text { Lezzet arayan kişiler için } \\
\text { Bizim olan tatların tanıtılması önemli } \\
\text { Kültürümüzü yansıtan şekilde olmalı } \\
\text { Daha iyi tanınsın } \\
\text { Tanıtmayı bilmeli } \\
\text { Turistlere karşı iyi bir izlenim bırakır } \\
\text { Yerel mutfak daha çok tanıtılmalı } \\
\text { Kendi kültürümüzü yansıtmalıyız } \\
\text { Tanıtımı yapılır } \\
\text { Yerel mutfak yayılmalı, bizim lezzetler bilinmeli } \\
\text { Kültürümüzü yansıtır } \\
\text { Kültürlerin tanınmasına ve mutfakta } \\
\text { uygulanmasına yardımcı olur } \\
\text { İlk önce yerel mutfağı öğrenmeli }\end{array}$ & $\begin{array}{l}\text { Kendi kültürümüzden uzaklaşmamak için } \\
\text { Kendi geleneklerimizi devam ettirmemiz lazım } \\
\text { Her ülkenin kendi benliğine ait olan yemekler } \\
\text { kaybolmamalı } \\
\text { Özümüzü kaybetmemek, tatlarımızı devam ettirmek } \\
\text { Bu bizim geçmişimiz, geleceğimiz. Unutulmamalı } \\
\text { Yemek kültürünün aktarılması önemli } \\
\text { İlk önce kendi mutfağımızın öğrenilmesi gereklidir } \\
\text { bence } \\
\text { Yemek kültürümüzü ilerletebilmeliyiz } \\
\text { Milli özgünlük unutulmamalı } \\
\text { Yerel mutfağın unutulmasına engel olmalıyız } \\
\text { Kültür kaybı olmaması için } \\
\text { Yemeklerimizi daha fazla aktarabilmeliyiz } \\
\text { Kültür kaybı en aza indirgenir } \\
\text { Diğer mutfaklardan geri kalmayıp bütün tekniklerle } \\
\text { gündemde kalması gerekir ( unutulmamak için) } \\
\text { Yerel mutfağın devamlılığını sağlar } \\
\text { Geleneklerimizi korumamıza yardımcı olur } \\
\text { İnsan özünü unutmamalı } \\
\text { Kendimize özgü lezzetlerimizi kaybediyoruz }\end{array}$ \\
\hline Gelişim & Farklılık \\
\hline $\begin{array}{l}\text { Gelişmemiz ve geliştirmemiz lazım } \\
\text { Türk mutfağı yenilikçi ve standartlara uygun ve } \\
\text { geliştirilebilir olmalıdır. } \\
\text { Türk mutfağını geliştirir } \\
\text { Kültür açısından gelişime yarar sağlar } \\
\text { Çok daha alıcıyı kendine çeker }\end{array}$ & $\begin{array}{l}\text { Farklı tatları dener insanlar } \\
\text { Çok çeşitli geleneksel yemeklerimiz var } \\
\text { Geleneksel seven bir toplumuz } \\
\text { Her bölgenin farklı tatları sunum için uygundur } \\
\text { Yeni lezzetler ortaya çıkar } \\
\text { Kafadaki sorulara yanıt olur }\end{array}$ \\
\hline Değer & Farkındalık \\
\hline $\begin{array}{l}\text { Değişikliklere ihtiyacımız var, aynı zamanda } \\
\text { markaya değer katar } \\
\text { Uygulanabilir uygulanmaya da bilir. Misafirlerin } \\
\text { demografik ön görüleri değerdir. } \\
\text { Yöresel yemeklerimiz dünya mutfağında değer } \\
\text { kazanır } \\
\text { Bizim kültürümüz daha sağlıklıdır } \\
\text { Kültürümüzü yansıtıyor. Toplum değerimizin } \\
\text { artacağını düşünüyorum } \\
\text { Biyolojik ve genetiğe göre, bulunan topraktan } \\
\text { çıan her şey daha lezzetlidir } \\
\text { Yerel mutfaklar ve sokak lezzetleri Türk } \\
\text { mutfağının vazgeçilmezidir } \\
\text { Türk mutfağı gibi yemek kültürü yoktur } \\
\text { Türk mutfağı tarihin izlerini taşır } \\
\text { Türk mutfağı değerini kaybetmemeli } \\
\text { Farklı kültürlerin yemekleri yanında değer } \\
\text { kazanır }\end{array}$ & $\begin{array}{l}\text { Yerel yemekler hakkında bilgi sahibi olmak hoşuma } \\
\text { gider } \\
\text { Her gıdanın özelliği ayrı } \\
\text { Bilinmeyen çok fazla yemeğimiz var } \\
\text { Yaratıcılığı yüksek bir mutfak } \\
\text { Yerel mutfak yaygınlaşmalı } \\
\text { Diğer yörelerden gelenlerin ilgisini çeker } \\
\text { Klasikler alışıla gelmiş olduğu için şık karşılanır } \\
\text { Bizim kültürümüzün bir parçasıdır } \\
\text { Kültürümüz artar } \\
\text { Her ülke kendi mutfağının değerini ve önemini } \\
\text { bilmelidir } \\
\text { İnsanların kendi kültürlerinden toplanması önemlidir } \\
\text { Bizde olan şeyleri bilmek öğrenmek gerekir } \\
\text { Her bölgenin yemeklerini, içeceklerini menüde görmek, } \\
\text { tatmak güzel olur. } \\
\text { Yerel mutfak yaygınlaşmalı }\end{array}$ \\
\hline
\end{tabular}


Yerel mutfağın menülerde kullanılması gerektiğini belirten katılımcıların öne sürdüğü görüşleri ortak özellikleri bakımından incelenmiş ve ortak özelliklere göre görüşler 6 kategoride sınıflandırılmıştır. Bu kategoriler "değer", "farkındalık”, "farklılık", "gelişim”, "kültürel sürdürülebilirlik" ve "tanıtım" olarak isimlendirilmiştir.

\section{Tartışma ve Sonuç}

Katılımcılar, Türk mutfağının farklı mutfaklar ile etkileşerek daha fazla değer kazanacağı konusunda görüş belirtmişlerdir. Bu etkileşim sonucunda yiyecek-içeceklerin farklı kültürlerle harmanlanması sonucu çeşitliliğin, lezzetin ve görselliğin zenginleşeceğine dair inanışa sahiptirler. Farklı mutfak uygulamalarının birleşmesiyle ortaya çıkan tatların yüksek oranda talebe neden olabileceği ve Türk mutfağının adından söz ettirebileceği, katılımcılar arasındaki yaygın görüş olarak karşımıza çıkmaktadır. Farklı kültürlerin yemek yeme noktasında birleşmesinin önemine değinen katılımcılar, bu durumun yeni lezzetlerin ortaya çıkmasında yaratıcı bir unsur olduğunu ve yerel gastronomik özelliklerin tanıtımında da etkin rol alabileceğini dile getirmişlerdir.

Mutfakta eski usulün gereğini savunan katılımcılara göre Türk insanının damak tadı değişime uygun değildir ve mevcut durumun korunması gerekmektedir. Her kültürün kendine has özellikleri olduğuna vurgu yapan katılımcılar, Türk mutfağının yeterince geniş çaplı olduğu, mutfağının bozulmaması, kültürel devamlılık adına özün korunması ve tadın kaymaması için füzyon mutfağın uygulanmaması yönünde görüş belirtmişlerdir.

Moleküler mutfak uygulaması ile oluşan sıra dışı yemeklerin Türk mutfağına olan ilgiyi arttırabileceği, yiyeceklerin kalitesinin yükselebileceği ve bu sayede Türk mutfağının daha da göz önünde olabileceği katılımcılar tarafindan öne sürülmüştür. Farklı teknik, tat, servis gibi bileşenlerinin Türk mutfağında kullanılmasının farklılık adına iyi olabileceğini savunan katılımcılar; gelişim adına gastronomi alanında daha iyi yerlere gelinebileceği, yenilikçiliğin müşteriyi memnun edebileceği ve aynı zamanda ülkemizin tanıtımına katkı sunabileceği için moleküler mutfağın Türk mutfağında uygulanmasını uygun bulmaktadırlar.

Aşçıların öncelikle Türk mutfağını öğrenmeleri gerektiğini savunan katılımcılar, moleküler mutfak uygulaması ile öz kültürden uzaklaşılabileceği, kültürel özerkliğin yok olabileceği ve orijinalliğin bozulması ile tatların değişebileceği kaygılarını taşımaktadırlar. Ayrıca yemek yapılırken kimyasal uygulamaların son derece sağlıksız ve endişe verici olduğu da bu kaygılar arasında yer almaktadır. Katılımcılara göre otantikliğin korunması; kültürel sürdürülebilirlik ve doğallık adına moleküler mutfak, Türk mutfağında uygulanmamalıdır.

Toplum değerlerinin artabileceği, gastronomide marka olunabileceği ve yöresel yemeklerin dünya mutfağında daha fazla göz önünde bulunabileceği gibi görüşler, Türk mutfağının daha değerli olabileceği düşüncesine dayanmaktadır. Yerel mutfağın menülerde uygulanması ile bilinmeyen 
yemeklerin gün yüzüne çıkabileceği ve ilgi çekebileceğine dair görüşler farkındalık oluşturması adına önem arz etmektedir. Yerel mutfağın sıklıkla menülerde kullanılması ile yeni lezzetlerin ortaya çıkabileceği ve yiyecek içecekte farklılık arayanlara hitap edilebileceği görüşlerini savunan katılımcılar, Türk mutfağının yenilikçi ve standartlara uygun ve geliştirilebilir yönüne vurgu yapmışlardır. Kendi öz kültürümüzün korunması ve aktarılması kültürel sürdürülebilirlik adına büyük önem taşırken yerel mutfağın menülerde kullanılmasının, ülke tanıtımında da etkin role sahip olduğu katılımcılar tarafından belirtilmiştir.

Analiz sonuçları, katılımcıların yenilikçi mutfak akımlarının yerel mutfak kültüründe olumlu gelişmelere neden olabileceğini, fakat bunun yanında öz yemek kültürünü değiştirebileceği ya da ortadan kaldırabileceği inanışlarının olduğunu göstermektedir. Alan araştırmasında çok sayıda soru formunun geri dönmesi ve gerekçe olarak bilgi yetersizliğinin öne sürülmesi, eğitim ve uygulamada yenilikçi mutfaklar konusundaki yanlış ve eksiklikleri göstermektedir. Bu durumun sektörel bazda hizmet içi eğitimlerle, okullarda ders içeriklerinin düzenlenmesi ile çözüme ulaştırılması gerekir. Füzyon mutfak ve moleküler mutfak uygulamaları için ülkemizin biraz daha zamana ihtiyacı bulunmaktadir.

Yerel yemek kültürü, mutfaklarda uygulanan yeniliklerle kaybolabilecek nitelikte basit bir yapıya sahip değildir. Bu kültürün gelecek nesillere aktarılmasında yenilikçi mutfak akımlarının uygulanması bir engel teşkil etmemektedir. Bu bilincin, özellikle eğitim alan ve yemek alanında uzmanlaşmak isteyen öğrencilere benimsetilebilmesi büyük önem arz etmektedir. Yenilikçi mutfaklar, farklılık ve çeşitlilik adına gerçekleştirilen uygulamalardır. Ülkemiz, bu tür uygulamalar için yeterince bol çeşitlilikte yiyecek ve içecek ürünleri açısından zengin kaynaklara sahip bir ülkedir.

Yiyecek içecek sektöründe çalışan ve bunun yanında bu konuda eğitim alan öğrencilerin yenilikçi mutfak akımları ile ilgili olmaları ve gerekli araştırmaları yaparak uygulamaya dökmeleri, mutfakta yenilikçilik uygulanmaları açısından önemli bir faktördür. Bir şefin haz aldığı mutfak akımını günlük menülerinde uygulaması ile kendisini mutfakta daha etkin kılabilmektedir. $\mathrm{Bu}$ tür mutfak uygulamalarının mutfak personelinin tabanına da yayılması sonucu, ortaya çıkan menülerde kültürel çeşitlilik yüksek seviyelerde olması kaçınılmazdır. Ama burada önemli olan unsur, yenilik uygulamalarının çalışanlar açısından benimsenmesidir. Dolayısıyla bu çalışmanın sonuçları, yenilikçi mutfak akımlarının mutfak personeli ve bu konuda eğitim alan kişilerce ne düzeyde anlaşıldığının belirlenmesi, işletmelere ürün geliştirme perspektifi açısından ışık tutmaktadır. 


\section{KAYNAKÇA}

Adlam, E.V. (2012). Fusion cuisine goes global: linkage of contients through food, Create Space Company, USA.

Akerdem, F. (2009). Moleküler kokteyller. Gusto Dergisi, 9(9), 30-37.

Aksoy, M. ve Üner, E., H. (2016). Rafine mutfağın doğuşu ve rafine mutfağı şekillendiren yenilikçi mutfak akımlarının yiyecek içecek işletmelerine etkileri. Gazi Üniversitesi Sosyal Bilimler Dergisi, 3(6), 117.

Avcıkurt, C., Sarıoğlu, M. ve Girgin, G. K. (2007). Yiyecek olgusuna sosyolojik bir bakış. Akdeniz Üniversitesi I. Gastronomi Sempozyumu, 1-7.

Barham, P., Skibsted, L. H., Bredie, W. L., Bom Frost, M., Moller, P., Risbo, J., Snitkjer, P., Mortensen, L. M. (2010). Molecular gastronomy: A New Emerging Scientific Discipline. Chemical Reviews. 110 (4); 2313-2365.

Blanck, J. F. (2007). Molecular gastronomy: overview of a controversial food science discipline, Journal of Agricultural \& Food Information, 8(3), 77-85.

Bucak, T. ve Aracı, Ü. E. (2013). Türkiye'de gastronomi turizmi üzerine genel bir değerlendirme. Ballkesir Üniversitesi Sosyal Bilimler Enstitüsü Dergisi, 16 (30), 203-216.

Can, A., Sünnetçioğlu, A. ve Durlu-Özkaya, F. (2012, 6-12 Aralık). Füzyon mutfak uygulamalarının gastronomi turizminin gelişimine etkisi. 13. Ulusal Turizm Kongresi. Akdeniz Üniversitesi Turizm Fakültesi, Antalya.

Doğdubay, M., Girgin G. K. ve Giritlioğlu İ., (2007, 21-23 Kasım). Yiyecek-İçecek Endüstrisinde Bir Pazarlama Stratejisi Olarak Ürün Geliştirme Çalışması (Füzyon Mutfak Uygulaması), I. Çeşme Ulusal Turizm Sempozyumu, 33-41.

Doğdubay, M., Şahin, N. N. ve Yiğit, S. (2017). In the fusion cuisine approach availability of quinoa (application suggestions). Journal of Tourism and Gastronomy Studies, 5(3), 3-12.

Durlu, Özkaya ve Özel, (2018). Moleküler mutfak tekniklerinden kapsülleştirme: standart reçete örnekleri. Journal of Tourism and Gastronomy Studies 6(83) 53-72.

Fırat M. (2014). Yemeğin ideolojisi ya da ideolojinin yemeği: kimlik bağlamında yemek kültürü. Folklor/edebiyat, 20(80), 129-140.

Gourmand, Breaks. (2015). What is Nouvelle Cuisine?. https://www.gourmandbreaks.com/blog/what-isnouvelle-cuisine/ (Erişim: 10.12.2020).

Hall, M. ve Mitchell, R. (2002). Tourism as a force for gastronomic globalization and localization. İçinde: A. M. Hjalager ve G. Richards (Ed.), Tourism and Gastronomy, London: Routledge, 71-97.

İnceöz, S. (2009). Turistlerin seyahat motivasyonunun belirlenmesinde Türk mutfağına yönelik bir durum değerlendirmesi, 3. Ulusal Gastronomi Sempozyumu ve Sanatsal Etkinlikler, Antalya.

Kanık, İ. (2016). Gastro gösteri. İstanbul:Ayrıntı Yayınları.

Karaca, B.O. ve Karacaoğlu, S. (2016). Kültür, din ve yemek etkileşimi çerçevesinde arap mutfağının kavramsal olarak incelenmesi: adana ili örneği. Hitit University Journal of Social Sciences Institute, 9(2), 561- 584. 
Karamustafa, K., Birdir, K. ve Kılıçhan, R. (2016). Gastronomik akımlar çerçevesinde gıda tüketim ölçeği. Tüketici ve Tüketim Araştırmaları Dergisi, 8(2): 29-69.

Kızıldemir, Ö., Öztürk, E ve Sarışık, M. (2014). Türk mutfak kültürünün tarihsel gelişiminde yaşanan değişimler, AIB̈Ü Sosyal Bilimler Enstitüsü Dergisi, 14(3), 191-210.

McWilliams, M. (2006). Eating postmodernity: Fusion cuisine and authenticity. R. Hosking (Ed.), Authenticity in the kitchen: Proceedings of the Oxford Symposium on food and cookery 2005 içinde (307-317). Devon: Prospect Books.

Mielby, L. H. \& Frøst, M. B. (2010). Expectations and surprise in a molecular gastronomic meal. Food Quality and Preference, 21, 213-224.

Okech, R. N. (2014, 11-13 Haziran). Developing culinary tourism: the role of food as a cultural heritage in kenya. proceedings of the second international conference on global business, economics, finance and social sciences (GB14Chennai Conference), Chennai, India. Sciences (GB14Chennai Conference), 11 - 13 July, Chennai, India.

Rao, H., Monin, P. ve Durand, R. (2003). Institutional change in Toque Ville: Nouvelle cuisine as an identity movement in French gastronomy. The American Journal of Sociology, 108(4): 795-843.

Sandıkçı, M. ve Çelik, S. (2007), 4-5 Mayıs). Füzyon mutfak uygulamaları ve misafir memnuniyeti açısından önemi. 1. Ulusal Gastronomi Sempozyumu, Antalya, 41-54.

Santich, B. (2004). The study of gastronomy and its relevance to hospitality education and training. Hospitality Management, 23 (1), 15-24.

Sarığlan, M. (2014). Fusion Cuisine Education and Its Relation with Molecular Gastronomy Education (Comparative Course Content Analysis), International Journal on New Trends in Education and Their Implications, 5(3), 64-70.

Stano, S. (2014). "Con-fusion cuisines": Melting foods and hybrid identities. Proceedings of the 12th World Congress of the International Association for Semiotic Studies (IASS/AIS), 16-20 Eylül, Sofya, Bulgaristan, 904-913.

Şengül, S. ve Türkay, O. (2015). Bölge restoran mönülerinin belirlenmesinde "yöresel mutfaklar" eğitiminin kullanılması: Mudurnu örneği. Electronic Journal of Vocational Colleges, UMYOS Özel Sayısı 1-6.

Tarınç, A., Yıldırım, G. ve Kılınç, C. Ç. (2019). Osmanlı Mutfağının Füzyon Mutfağı Çerçevesinde Değerlendirilmesi. Journal of Socıal and Humanities Sciences Research. 4(43),3045-3053.

This, H. (2013). Celebrate chemistry. recent results of molecular gastronomy. European Review, 21(2): 158.

Turan, H., Başaran., G., Ayduğ, İ., Bayesen, D. ve Sünnetçioğlu, S. (2020). Mutfak şeflerinin füzyon mutfağa yönelik görüşleri ve çanakkale iline ait yöresel gıdalar ile füzyon mutfak önerileri. AHBVÜ Turizm Fakültesi Dergisi, 23 (2), 332-358.

Uyar, H. ve Zengin, B. (2015). Gastronomi turizminin alternatif turizm çeşidi olarak değerlendirilmesi bağlamında gastronomi turizm indeksinin oluşturulması. Akademik Sosyal Araştırmalar Dergisi, 3 (17), 355-376

Vega, C. ve Ubbink, J. (2008). Molecular gastronomy: a food fad or science supporting innovative cuisine? Trends in Food Science and Technology, 19: 372-382.

Yıldırım Saçılık, M. ve Baysal, K. (2019, 23-27 Ekim). "Yemek" ve "mutfak" olgularına ilişkin önlisans öğrencilerinin metaforik algıları. 4. Gençlik Araştırmaları Kongresi, Marmaris, 85-102. 
Yıldırım-Saçılık / Turizm ve İşletmecilik Dergisi /

Journal of Tourism and Management, 2020, Vol. 1 (1), 21-39

Yıldırım, Ş. ve Şimşek, H. (2011).Sosyal bilimlerde nitel Araştırma yöntemleri. (8. Basım). Seçkin Yayınc1lık, Ankara. 